\title{
稀土席夫碱配合物催化己内酯可控开环聚合
}

\author{
倪旭峰，朱伟伟，沈之荃 \\ 浙江大学高分子科学与工程学系, 教育部高分子合成与功能构造重点实验室, 浙江杭州 310027
}

\begin{abstract}
摘要: 通过稀土氯化物与席夫碱钠盐的交换反应制备了一系列以 3,5 -二叔丁基水杨醛缩苯胺为配体的稀土席夫碱配合物. 对其 中的钕席夫碱配合物进行了 X射线单晶衍射分析, 发现其单晶结构为五角双锥构型, 所得席夫碱稀土配合物可以单组分催化 $\varepsilon$ 己内酯开环聚合. 深入研究了钽席夫碱配合物催化己内酯的开环聚合机理, 考察了不同聚合条件对单体转化率、产物分子量及 分子量分布的影响. 结果表明, 该聚合反应速率为一级, 聚合反应具有较好的可控性. 聚合物端基分析表明, 聚合反应以配位-插 入机理进行.
\end{abstract}

关键词: 己内酯; 开环聚合; 稀土催化剂; 席夫碱; 晶体结构

中图分类号: 0643 文献标识码: A

\section{Controlled Ring-Opening Polymerization of $\varepsilon$-Caprolactone Catalyzed by a Rare Earth Schiff-Base Complex}

\author{
NI Xufeng ${ }^{\#}$, ZHU Weiwei, SHEN Zhiquan* \\ MOE Key Laboratory of Macromolecular Synthesis and Functionalization, Department of Polymer Science and Engineering, \\ Zhejiang University, Hangzhou 310027, Zhejiang, China
}

\begin{abstract}
Lanthanide Schiff-base complexes with the formula [3,5- $\left.t \mathrm{Bu}_{2}-2-(\mathrm{O}) \mathrm{C}_{6} \mathrm{H}_{2} \mathrm{CH}=\mathrm{NC}_{6} \mathrm{H}_{5}\right]_{3} \mathrm{Ln}(\mathrm{THF})(\mathrm{Ln}=\mathrm{Sc}, \mathrm{Y}, \mathrm{La}, \mathrm{Nd}$, and $\mathrm{Gd})$ were synthesized by the metathesis reaction of anhydrous $\mathrm{LnCl}_{3}$ with a Schiff-base sodium salt in good yields ( $\left.>80 \%\right)$. The complex containing a neodymium center was characterized by X-ray diffraction and the structure around the neodymium atom could be described as a pentagonal bipyramid. The ring-opening polymerization (ROP) of $\varepsilon$-caprolactone (CL) was successfully carried out using the lanthanide Schiff-base complexes as catalysts, and the neodymium complex leads to a controlled ROP of CL. The influence of the reaction conditions on the monomer conversion, molecular weight, and molecular weight distribution of the resultant polymers was investigated. The polymerization rate was first-order with respect to the monomer concentration. End-group analyses of the oligomer of CL showed that the polymerization underwent a coordination-insertion mechanism.
\end{abstract}

Key words: $\varepsilon$-caprolactone; ring-opening polymerization; rare-earth catalyst; Schiff-base; crystal structure

Aliphatic polyester poly( $\varepsilon$-caprolactone) (PCL) is biodegradable and biocompatible [1] and is attracting interest because of its numerous applications in the biomedical field. An efficient way to synthesize PCL is by the metal complex catalyzed ring-opening polymerization (ROP) of $\varepsilon$-caprolactone (CL). Therefore, the development of simple, convenient, and efficient metal complexes as catalysts for the ROP of $\varepsilon$-caprolactone is important practically and theoretically. Catalysts for CL polymerization are tradition- ally based on Sn, Al, Zns and lanthanide compounds [2-7]. Rare earth complexes are very attractive catalysts because of their low toxicity, low cost, and high reactivity [8-11].

Schiff-base ligands are considered to be privileged ligands and they are some of the most widely used non-cyclopentadienyl compounds in the coordination chemistry of transition and lanthanide metals [12]. They have also played an important role in progressing coordination chemistry over the past two decades [13]. Because

\footnotetext{
Received date: 26 March 2010.

*Corresponding author. Tel: +86-571-87953739; Fax:+86-571-87953727; E-mail: zhiquan_shen@163.com

\#Corresponding author. Tel: +86-571-87953739; Fax: +86-571-87953727; E-mail: xufengni@zju.edu.cn

Foundation item: Supported by the National Natural Science Foundation of China (20774078), the Special Funds for National Basic Research Program of China (973 Program, G2005CB623802), and the Scientific Research Foundation for Returned Scholars, Ministry of Education of China.

English edition available online at ScienceDirect (http://www.sciencedirect.com/science/journal/18722067).
} 
Schiff-base ligands have a hard donor atom framework and tunable steric and electronic effects, many metal Schiff-base complexes show high catalytic activity in various reactions [14-17]. Furthermore, the phenoxy-imine (FI) complexes of nickel (II) and the bis(phenoxyimine) group 4 metal complexes have been used as excellent catalysts for the polymerization of olefins [18-21]. Few rare earth Schiff base complex catalysts have been reported for the ring-opening polymerization of cyclic esters as well as the related lactides [22-24]. In these catalytic reactions, Schiff-base ligands are stable and act as ancillary ligands to stabilize the Ln-active bond.

Our group has developed some rare earth complexes as catalysts for the ROP of cyclic esters and they have worked very well [25-31]. We synthesized rare earth complexes bearing three Schiff-base ligands $\left(\left[3,5-t \mathrm{Bu}_{2}-2-(\mathrm{O}) \mathrm{C}_{6} \mathrm{H}_{2}-\right.\right.$ $\left.\mathrm{CH}=\mathrm{NC}_{6} \mathrm{H}_{5}\right]_{3} \mathrm{Ln}(\mathrm{THF})$ ) by a facile reaction between anhydrous rare earth chlorides and a Schiff-base sodium salt. They were thus employed as single component catalysts for the controlled ROP of CL.

\section{Experimental}

\subsection{General}

All experiments were performed under argon with the rigorous exclusion of air and moisture using standard Schlenk techniques. Toluene, $n$-hexane, and tetrahydrofuran (THF) were refluxed over sodium/benzophenone and distilled just before use. $\varepsilon$-Caprolactone was purchased from Acros, dried over $\mathrm{CaH}_{2}$ for $4 \mathrm{~d}$ and stored over $4 \mathrm{~A}$ molecular sieves under argon after distillation under reduced pressure. Anhydrous rare earth chloride was prepared from $\mathrm{Ln}_{2} \mathrm{O}_{3}$ and $\mathrm{HCl}$ in accordance with a standard procedure [32]. Other reagents were used as received.

Elemental analysis was performed on a Flash EA1112 instrument and the rare earth metal content was measured using the EDTA-titration method. ${ }^{1} \mathrm{H}$ NMR spectra were obtained on a Bruker Avance DMX500 spectrometer in $\mathrm{CDCl}_{3}$ at $25{ }^{\circ} \mathrm{C}$ with TMS as an internal reference. The molecular weight $\left(M_{\mathrm{n}}\right)$ and molecular weight distributions (MWD) of the formed polymers were measured by gel per- meation chromatography (GPC) at $40{ }^{\circ} \mathrm{C}$ using THF as eluent at a flow rate of $1.0 \mathrm{ml} / \mathrm{min}$ against standard polystyrenes on a Waters 1515 apparatus with three PL Mixed-C columns. FT-IR spectra of the samples were measured as $\mathrm{KBr}$ pellets using a Bruker Vector 22 FT-IR spectrometer. $\mathrm{X}$-ray diffraction (XRD) was performed as described below: suitable single crystals of a complex were sealed in thin-walled glass capillaries, and data collection was performed at $20{ }^{\circ} \mathrm{C}$ on a Bruker SMART diffractometer with graphite-monochromated Mo $K_{\alpha}$ radiation $(\lambda=0.071073$ $\mathrm{nm})$. The SMART program package was used to determine the unit-cell parameters. An absorption correction was applied using SADABS. The crystal structures of the neodymium containing complex was solved by a direct method using the SHELXS-97 program and expanded by the Fourier technique. All the non-hydrogen atoms were refined anisotropically. Hydrogen atoms were all generated geometrically ( $\mathrm{C}-\mathrm{H}$ bond lengths fixed at $0.95 \AA$ ) with assigned appropriate isotropic thermal parameters.

\subsection{Synthesis of $N$-phenyl-3,5-di-tert-butyl- salicylaldimine}

3,5-Di-tert-butyl-salicylaldehyde (16.5 g, $0.07 \mathrm{~mol})$ was dissolved in $30 \mathrm{ml}$ ethanol, phenylamine $(6.5 \mathrm{ml}, 0.07 \mathrm{~mol})$ was added dropwise into the solution. Then, the mixture was heated and refluxed for $3 \mathrm{~h}$. Orange crystals formed after the reaction solution cooled to room temperature. The fine crystalline product was then filtered and recrystallized in ethanol $(10.7 \mathrm{~g}, 49.4 \%)$. Anal. Calc. for $\mathrm{C}_{21} \mathrm{H}_{27} \mathrm{NO}$ : C, 81.51; H, 8.79; N, 4.53. Found: C, 81.81; H, 8.84; N, 4.59. ${ }^{1} \mathrm{H}$ NMR: $\delta=1.33-1.48\left(\mathrm{~m}, 18 \mathrm{H},-\mathrm{CH}_{3}\right), 7.22-7.45(\mathrm{~m}, 7 \mathrm{H}$, phenyl-H), $8.63(\mathrm{~s}, 1 \mathrm{H}, \mathrm{CH}=\mathrm{N}), 13.69(\mathrm{~s}, 1 \mathrm{H},-\mathrm{OH})$.

\subsection{Synthesis of $\left[3,5-t \mathrm{Bu}_{2}-2-(\mathrm{O}) \mathrm{C}_{6} \mathrm{H}_{2} \mathrm{CH}=\mathrm{NC}_{6} \mathrm{H}_{5}\right]_{3} \mathrm{Nd}$ (THF) complex (1)}

As shown in Scheme 1, $\mathrm{NdCl}_{3}(0.54 \mathrm{~g}, 2.15 \mathrm{mmol})$ was suspended in $20 \mathrm{ml}$ THF and stirred overnight at room temperature. A THF solution $(20 \mathrm{ml})$ of $\mathrm{N}$-phenyl- 3,5-di-tertbutyl-salicylaldimine $(2.17 \mathrm{~g}, 7.0 \mathrm{mmol})$ was added dropwise to a THF $(10 \mathrm{ml})$ suspension of $\mathrm{NaH}(0.20 \mathrm{~g}, 8.30$


Scheme 1. Synthesis and structure of rare earth Schiff-base complexes. 
mmol) at room temperature and further stirred for $4 \mathrm{~h}$. After filtration, the yellow solution was added to the $\mathrm{NdCl}_{3}$-THF suspension. The mixture was stirred at $80{ }^{\circ} \mathrm{C}$ in an oil bath for $4 \mathrm{~d}$ and then the formed precipitate was separated from the reaction mixture by centrifugation. The solvent was vaporized under reduced pressure and the residue was dissolved in $n$-hexane. $\quad\left[3,5-t \mathrm{Bu}_{2}-2-(\mathrm{O}) \mathrm{C}_{6} \mathrm{H}_{2} \mathrm{CH}=\right.$ $\left.\mathrm{NC}_{6} \mathrm{H}_{5}\right]_{3}-\mathrm{Nd}$ (THF) was isolated as yellow crystals at room temperature after a few days $(1.67 \mathrm{~g}, 53.8 \%)$. Anal. Calc. for $\mathrm{C}_{67} \mathrm{H}_{86} \mathrm{~N}_{3} \mathrm{NdO}_{4}$ : C, 70.49; H, 7.59; N, 3.68; Nd, 12.63 . Found: C, 70.64; H, 7.72; N, 3.74; Nd, 12.78\%. IR (KBr, $\mathrm{cm}^{-1}$ ): 2957 (s), 2903 (s), 2867 (s), 1608 (s), 1585 (s), 1546 (s), 1532 (s), 1484 (s), 1459 (s), 1430 (s), 1413 (s), 1384 (s), 1359 (s), 1320 (s), 1273 (s), 1256 (s), 1190 (s), 1164 (s), 1026 (s), 985 (w), 920 (w), 874 (m), 835 (s), 788 (m), $764(\mathrm{~m}), 742(\mathrm{~s}), 699(\mathrm{w}), 638(\mathrm{w}), 519(\mathrm{~s})$.

The other rare earth Schiff-base complexes were synthesized by the same method described above.

\subsection{Polymerization of $\mathrm{CL}$}

All polymerizations were carried out in $20 \mathrm{ml}$ ampoules using the Schlenk technique under argon. The catalyst was dissolved in toluene at a concentration of $2.0 \mathrm{~mol} / \mathrm{L}$. As a typical example, $0.55 \mathrm{ml}(5.0 \mathrm{mmol}) \mathrm{CL}$ and the desired amount of solvent and catalyst solution were injected into a flame-dried ampoule sequentially at a specific temperature and polymerized over a predefined time. The polymerization was terminated by adding ethanol containing $5 \% \mathrm{HCl}$ and the solution was poured into excess ethanol to precipitate the product, filtered and dried in vacuum at room temperature for $24 \mathrm{~h}$ to constant weight.

\subsection{Oligomer for the end-group analysis}

The oligomerization of $\mathrm{CL}$ was carried out with the $\mathrm{Nd}$ containing complex 1 in toluene at $30{ }^{\circ} \mathrm{C}$ with $[\mathrm{CL}] /[\mathrm{Nd}]=$ 20 and a monomer concentration $[\mathrm{CL}]=2.0 \mathrm{~mol} / \mathrm{L}$. The reaction was terminated with isopropanol containing $5 \%$ $\mathrm{HCl}$ after $5 \mathrm{~min}$. The oligomer was precipitated from ethanol and purified by redissolving in THF, followed by precipitation in ethanol. After filtration, the product was dried in vacuum for $24 \mathrm{~h}$.

\section{Results and Discussion}

\subsection{Synthesis and characterization of the lanthanide Schiff-base complexes}

The lanthanide Schiff-base complexes were synthesized by a salt metathesis reaction between $\mathrm{LnCl}_{3}$ and Schiff-base sodium salts in a non-aqueous solution. Anhydrous $\mathrm{LnCl}_{3}$ reacted with three equivalents of the sodium salts of the Schiff-bases formed in situ by the reaction of $N$-phenyl-3,5di-tert-butyl-salicylaldimine with $\mathrm{NaH}$ in THF, giving complexes in isolated yields of up to $80 \%$. All these complexes have good solubility in THF, toluene, and even in hexane.

Among the above-mentioned complexes, only the neodymium complex (complex 1) provided a suitable single crystal for X-ray structural determination. Complex $\mathbf{1}$ was also characterized by elemental analysis and FT-IR. In the IR spectrum of complex 1 , stretching vibration bands due to imine groups at $1608 \mathrm{~cm}^{-1}$ were observed. The paramagnetic property of complex 1 did not allow a resolvable NMR spectrum to be obtained. A definitive solid-state structure of

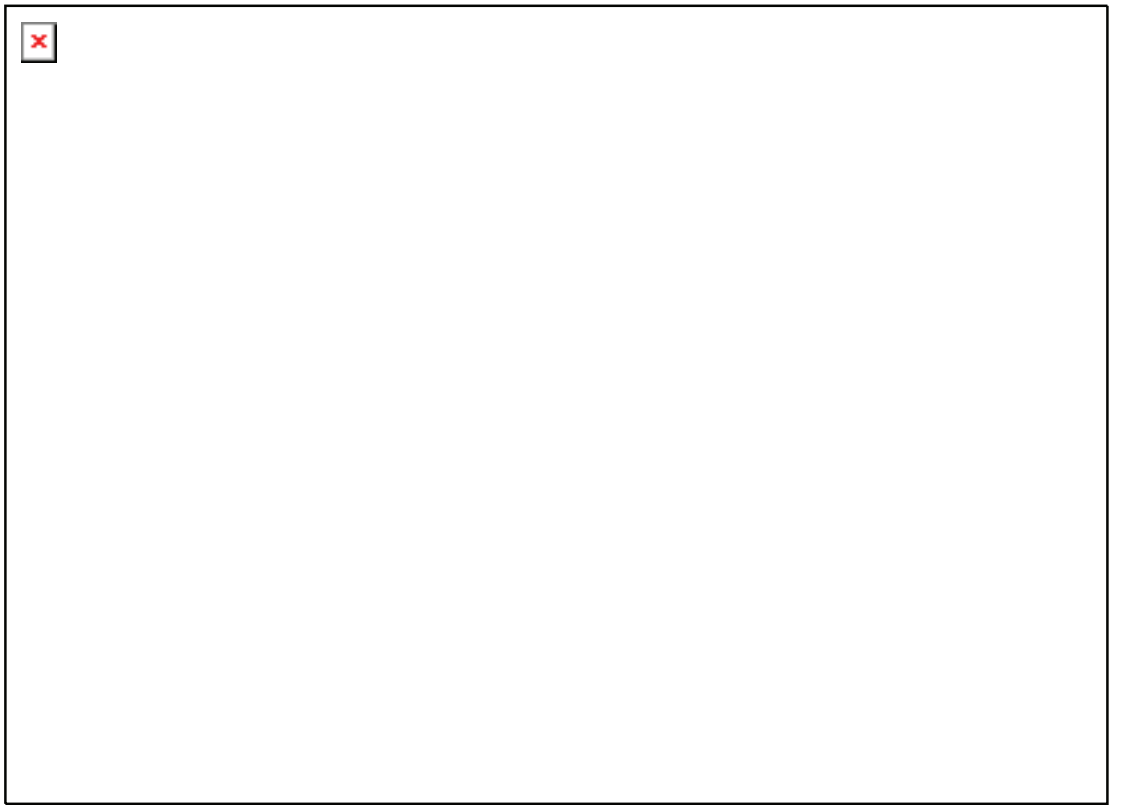

Fig. 1. ORTEP view of complex 1 with atom labels and showing $25 \%$ probability displacement ellipsoids. 
Table 1 Crystallographic data and selected bond lengths and angles for the $\mathrm{Nd}$ containing complex 1

\begin{tabular}{|c|c|c|c|}
\hline Parameter & Value & Parameter & Value \\
\hline Empirical formula & $\mathrm{C}_{67} \mathrm{H}_{86} \mathrm{~N}_{3} \mathrm{NdO}_{4}$ & $R(\mathrm{Nd} 1-\mathrm{O} 2) / \mathrm{nm}$ & $0.2215(5)$ \\
\hline Formula weight $(\mathrm{g} / \mathrm{mol})$ & 1141.63 & $R(\mathrm{Nd} 1-\mathrm{O} 3) / \mathrm{nm}$ & $0.2226(5)$ \\
\hline Temperature $\left({ }^{\circ} \mathrm{C}\right)$ & $23(1)$ & $R(\mathrm{Nd} 1-\mathrm{O} 4) / \mathrm{nm}$ & $0.2547(2)$ \\
\hline Wavelength (nm) & 0.071073 & $R(\mathrm{Nd} 1-\mathrm{N} 1) / \mathrm{nm}$ & $0.2691(6)$ \\
\hline Crystal system & triclinic & $R(\mathrm{Nd} 1-\mathrm{N} 2) / \mathrm{nm}$ & $0.2697(6)$ \\
\hline Space group & P-1 (2) & $R(\mathrm{Nd} 1-\mathrm{N} 3) / \mathrm{nm}$ & $0.2699(6)$ \\
\hline$a / \mathrm{nm}$ & $1.14235(6)$ & $\angle \mathrm{O} 2-\mathrm{Nd} 1-\mathrm{O} 3 /\left(^{\circ}\right)$ & $166.57(17)$ \\
\hline$b / \mathrm{nm}$ & $1.63503(8)$ & $\angle \mathrm{O} 2-\mathrm{Nd} 1-\mathrm{O} 1 /\left(^{\circ}\right)$ & $93.15(18)$ \\
\hline $\mathrm{c} / \mathrm{nm}$ & $1.71564(9)$ & $\angle \mathrm{O} 3-\mathrm{Nd} 1-\mathrm{O} 1 /\left(^{\circ}\right)$ & $90.10(18)$ \\
\hline$\alpha /\left(^{\circ}\right)$ & $79.5588(16)$ & $\angle \mathrm{O} 2-\mathrm{Nd} 1-\mathrm{O} 4 /\left(^{\circ}\right)$ & $90.94(14)$ \\
\hline$\beta /\left(^{\circ}\right)$ & $85.2927(13)$ & $\angle \mathrm{O} 3-\mathrm{Nd} 1-\mathrm{O} 4 /\left(^{\circ}\right)$ & $94.06(13)$ \\
\hline$\gamma /\left(^{\circ}\right)$ & $79.9808(16)$ & $\angle \mathrm{O} 1-\mathrm{Nd} 1-\mathrm{O} 4 /\left(^{\circ}\right)$ & $144.08(15)$ \\
\hline$V / \mathrm{nm}^{3}$ & $3.0991(3)$ & $\angle \mathrm{O} 2-\mathrm{Nd} 1-\mathrm{N} 1 /\left(^{\circ}\right)$ & $89.55(18)$ \\
\hline$Z$ & 2 & $\angle \mathrm{O} 3-\mathrm{Nd} 1-\mathrm{N} 1 /\left(^{\circ}\right)$ & $103.79(18)$ \\
\hline$D_{\text {calc }} /\left(\mathrm{g} / \mathrm{cm}^{3}\right)$ & 1.22333 & $\angle \mathrm{O} 1-\mathrm{Nd} 1-\mathrm{N} 1 /\left(^{\circ}\right)$ & $69.80(16)$ \\
\hline$\mu / \mathrm{mm}^{-1}$ & 0.885 & $\angle \mathrm{O} 4-\mathrm{Nd} 1-\mathrm{N} 1 /\left(^{\circ}\right)$ & $74.56(15)$ \\
\hline$F(000)$ & 1202 & $\angle \mathrm{O} 2-\mathrm{Nd} 1-\mathrm{N} 3 /\left(^{\circ}\right)$ & $97.48(18)$ \\
\hline Crystal size (mm) & $0.19 \times 0.18 \times 0.08$ & $\angle \mathrm{O} 3-\mathrm{Nd} 1-\mathrm{N} 3 /\left(^{\circ}\right)$ & $69.98(17)$ \\
\hline $2 \theta$ range $\left({ }^{\circ}\right)$ & 51.0 & $\left.\angle \mathrm{O} 1-\mathrm{Nd} 1-\mathrm{N} 3 / \mathrm{(}^{\circ}\right)$ & $83.01(17)$ \\
\hline Reflections collected & 25672 & $\angle \mathrm{O} 4-\mathrm{Nd} 1-\mathrm{N} 3 /\left(^{\circ}\right)$ & $131.73(15)$ \\
\hline Independent reflections & 11384 & $\angle \mathrm{N} 1-\mathrm{Nd} 1-\mathrm{N} 3 /\left(^{\circ}\right)$ & $152.28(17)$ \\
\hline Reflections with $I \geq 2.0 \sigma$ (I) & 5690 & $\angle \mathrm{O} 2-\mathrm{Nd} 1-\mathrm{N} 2 /\left(^{\circ}\right)$ & $68.62(17)$ \\
\hline Parameters refine & 695 & $\angle \mathrm{O} 3-\mathrm{Nd} 1-\mathrm{N} 2 /\left(^{\circ}\right)$ & $101.63(18)$ \\
\hline Goodness-of-fit on $F^{2}$ & 1.053 & $\angle \mathrm{O} 1-\mathrm{Nd} 1-\mathrm{N} 2 /\left(^{\circ}\right)$ & $144.54(18)$ \\
\hline$R$ & 0.0768 & $\angle \mathrm{O} 4-\mathrm{Nd} 1-\mathrm{N} 2 /\left(^{\circ}\right)$ & $69.04(16)$ \\
\hline$W R$ & 0.1435 & $\angle \mathrm{N} 1-\mathrm{Nd} 1-\mathrm{N} 2 /\left(^{\circ}\right)$ & $136.58(17)$ \\
\hline$R(\mathrm{Nd} 1-\mathrm{O} 1) / \mathrm{nm}$ & $0.2268(4)$ & $\angle \mathrm{N} 3-\mathrm{Nd} 1-\mathrm{N} 2 /\left(^{\circ}\right)$ & $70.27(17)$ \\
\hline
\end{tabular}

complex 1 was provided by a single crystal X-ray determination. The ORTEP diagram of complex $\mathbf{1}$ is shown in Fig. 1 , and the corresponding crystallographic data are given in Table 1. The selected bond lengths and angles are also listed in Table 1 . The neodymium ion in complex $\mathbf{1}$ is ligated by three salicyladiminato ligands and a THF molecule. The geometry around the seven-coordinate neodymium metal center can be best described as a distorted pentagonal bipyramidal geometry (Fig. 2) with two oxygen atoms (O2, O3) from the Schiff-base ligands occupying the axial positions while two oxygen atoms $(\mathrm{O} 4, \mathrm{O} 1)$ and three nitrogen atoms (N1, N2, and N3) form a plane. The average
$\mathrm{Nd}-\mathrm{N}$ (Schiff-base) distance in complex $\mathbf{1}$ is $0.2696 \mathrm{~nm}$ and the average $\mathrm{Nd}-\mathrm{O}(\mathrm{Ar})$ bond length is $0.2236 \mathrm{~nm}$.

\subsection{Polymerization of CL as catalyzed by the lanthanide Schiff-base complexes}

The polymerization of CL was initially performed with various rare earth Schiff-base complexes $\left(\operatorname{Ln}(\operatorname{Salen})_{3}\right)(\mathrm{Ln}=$ Sc, Y, La, Nd, and Gd) as shown in Table 2. We found that the yttrium complex had the highest catalytic activity for the ROP of CL under certain conditions and the scandium complex showed almost no catalytic activity for the ROP of CL.
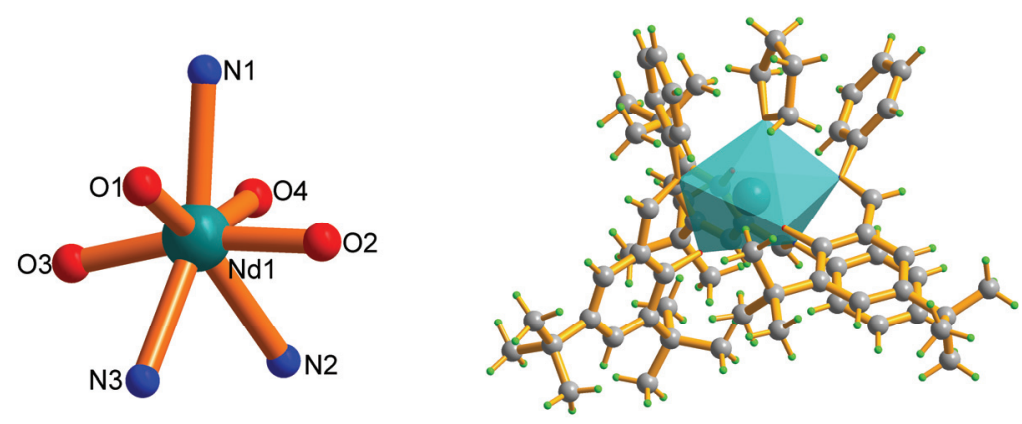

Fig. 2. Conformation of the neodymium complex. 
Table 2 ROP of CL catalyzed by $\mathrm{Ln}(\text { Salen })_{3}$

\begin{tabular}{crccccc}
\hline Element $n(\mathrm{CL}) / n(\mathrm{Ln})$ & $T /{ }^{\circ} \mathrm{C}$ & $t /$ min & Conversion (\%) & $M_{\mathrm{n}}{ }^{\mathrm{a}}$ & $\mathrm{MWD}$ \\
\hline $\mathrm{Y}$ & 100 & 50 & 30 & 100 & 19200 & 1.31 \\
$\mathrm{Y}$ & 200 & 50 & 30 & 74.5 & 33400 & 1.30 \\
$\mathrm{Nd}$ & 50 & 50 & 30 & 100 & 15800 & 1.34 \\
$\mathrm{Nd}$ & 100 & 50 & 30 & 100 & 18300 & 1.42 \\
$\mathrm{Nd}$ & 200 & 50 & 30 & 51.5 & 26100 & 1.38 \\
$\mathrm{La}$ & 50 & 50 & 30 & 100 & 9600 & 1.14 \\
$\mathrm{La}$ & 100 & 50 & 30 & 55.8 & 11400 & 1.18 \\
$\mathrm{Gd}$ & 50 & 50 & 30 & 90.0 & 17700 & 1.47 \\
$\mathrm{Gd}$ & 100 & 50 & 30 & 43.3 & 18900 & 1.51 \\
$\mathrm{Sc}$ & 50 & 50 & 60 & - & - & - \\
$\mathrm{Sc}$ & 100 & 50 & 60 & - & - & - \\
$\mathrm{Nd}$ & 100 & 30 & 60 & 88.2 & 10400 & 1.52 \\
$\mathrm{Nd}$ & 200 & 30 & 60 & 41.7 & 13800 & 1.66 \\
$\mathrm{Nd}$ & 100 & 10 & 60 & - & - & - \\
\hline
\end{tabular}

General polymerization conditions: $[\mathrm{CL}]=2.0 \mathrm{~mol} / \mathrm{L}$ in toluene.

${ }^{\text {a }}$ Measured by GPC against standard PSt samples.

The catalytic activity sequence for the different rare earth elements is $\mathrm{Y}>\mathrm{Nd}>\mathrm{La}>\mathrm{Gd}>\mathrm{Sc}$. The ROP of CL was also carried out with the neodymium complex as a catalyst at 10 and $30^{\circ} \mathrm{C}$. A higher reaction temperature favors ROP of CL. Only a small amount of PCL was isolated at $10^{\circ} \mathrm{C}$.

We also found that the neodymium complex acts as an active single-component catalyst for the ROP of CL and gives a polymer with a high molecular weight and a reasonably narrow MWD. The polymerization process of the CL catalyzed by the neodymium complex was investigated in detail and the results are shown in Figs. 3-5.

When the $\mathrm{CL} / \mathrm{Nd}$ molar ratio increases, the molecular weight of PCL increases linearly while the MWD broadens slightly from 1.33 to 1.52 , as shown in Fig. 3. The kinetics of the polymerization reaction at $50{ }^{\circ} \mathrm{C}$ in toluene with a $\mathrm{CL} / \mathrm{Nd}$ molar ratio of 200 was determined. The conversion increases as the polymerization time increases and a first-order kinetics plot of the polymerization is shown in

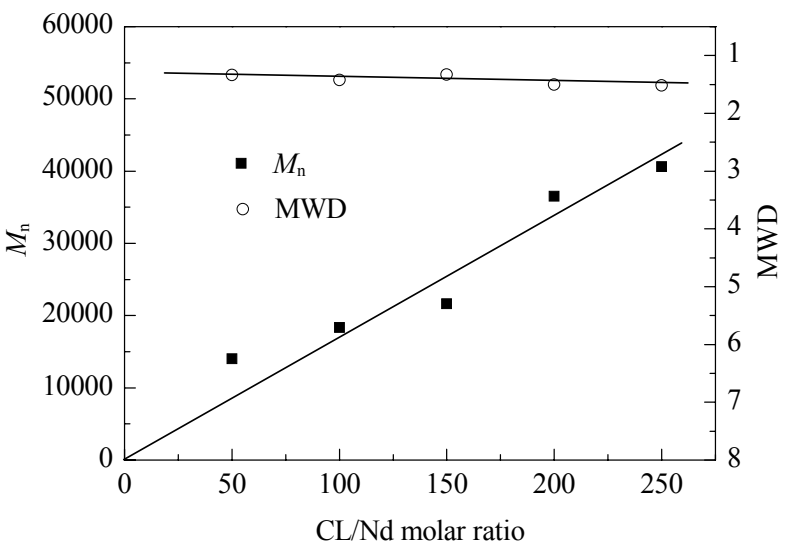

Fig. 3. Relationship between the $M_{\mathrm{n}}$ of PCL and the concentration of complex 1. Polymerization conditions: $[\mathrm{CL}]=2.0 \mathrm{~mol} / \mathrm{L}$ in toluene, 50 ${ }^{\circ} \mathrm{C}$.
Fig. 4. Figure 5 indicates that the number-average molecular weight $M_{\mathrm{n}}$ of PCL increases proportionally to the monomer conversion while the MWD of the polymer remains $\leq 1.50$. All these results indicate that the polymerization of $\mathrm{CL}$ catalyzed by the neodymium containing complex $\mathbf{1}$ is controllable.

To study the polymerization mechanism, a sample of low molecular weight PCL quenched with isopropanol was prepared and subjected to ${ }^{1} \mathrm{H}$ NMR analysis as shown in Fig. 6.

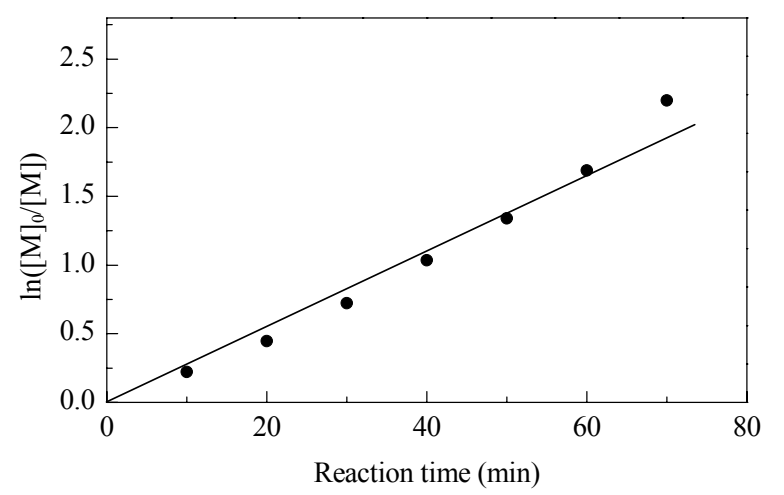

Fig. 4. Plot of $\ln \left([\mathrm{M}]_{0} /[\mathrm{M}]\right)$ versus reaction time for the polymerization of CL. Polymerization conditions: CL/Nd molar ratio $=200$, and the rest is the same as in Fig. 3.

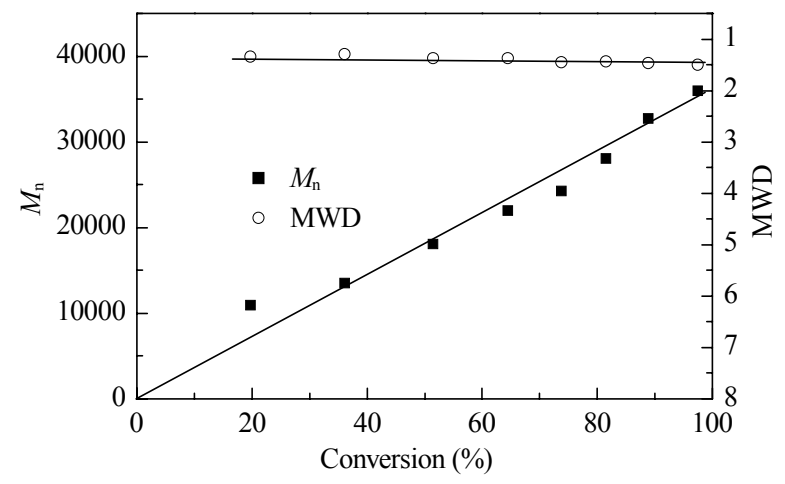

Fig. 5. Plots of $M_{\mathrm{n}}$ versus monomer conversion. Polymerization conditions are the same as in Fig. 4.

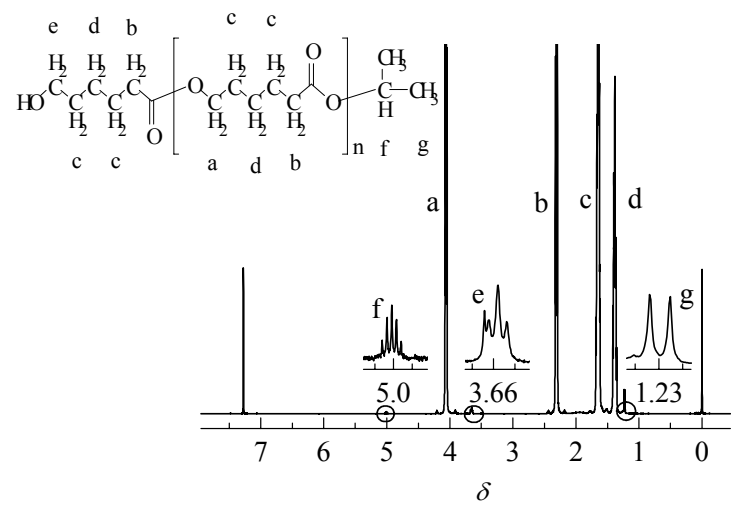

Fig. 6. ${ }^{1}$ H NMR spectrum of the PCL sample terminated by isopropanol. 


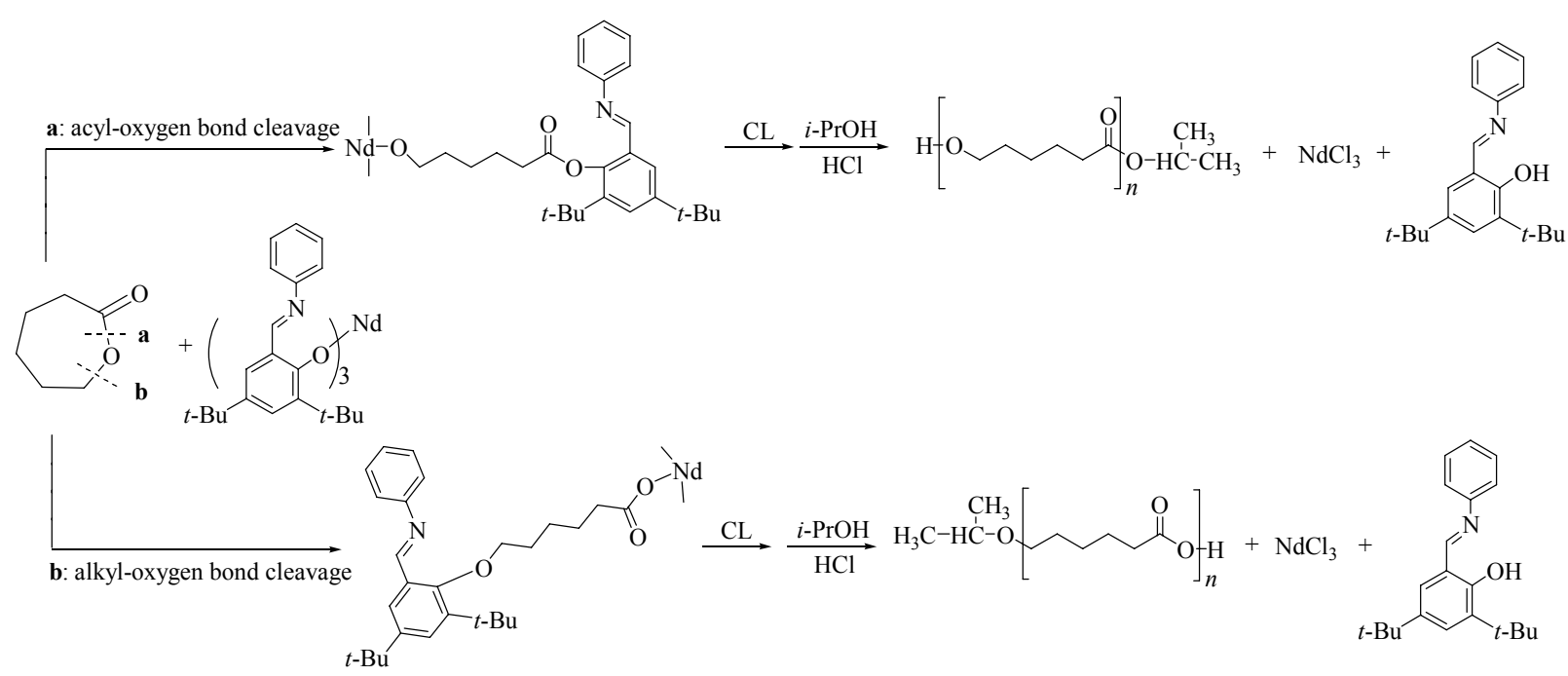

Scheme 2. Initiation and termination reaction modes in the ROP of CL.

One end of the PCL chain is the esterified isopropyl group $-\mathrm{COOCH}\left(\mathrm{CH}_{3}\right)_{2}$ according to the signals at $\delta=4.98$ (multiplet, $\mathrm{H}^{\mathrm{f}}$ ) for the $\mathrm{CH}$ group and $\delta=1.23$ (doublet, $\mathrm{H}^{\mathrm{g}}$ ) for the $\mathrm{CH}_{3}$ groups. Furthermore, the other end of the chain is $-\mathrm{CH}_{2} \mathrm{OH}$ according to the methylene proton signal at $\delta=$ 3.63 (triplet, $\mathrm{H}^{\mathrm{e}}$ ). These signals prove that the ring of $\mathrm{CL}$ opened by acyl-oxygen bond cleavage (Scheme 2a). On the contrary, no isopropyl ether end group signal is detected in the ${ }^{1} \mathrm{H}$ NMR spectrum, indicating that the ring of CL does not open by a break of the alkyl-oxygen bond (Scheme $2 \mathbf{b}$ ). This type of ring opening is similar to that previously reported [33].

\section{Conclusions}

Lanthanide Schiff-base complexes [3,5- $t \mathrm{Bu}_{2}-2-$ (O) $\left.\mathrm{C}_{6} \mathrm{H}_{2} \mathrm{CH}=\mathrm{NC}_{6} \mathrm{H}_{5}\right]_{3} \mathrm{Ln}$ (THF) were prepared by the reaction of anhydrous $\mathrm{LnCl}_{3}$ with the sodium salts of Schiff-bases in THF with a 3:1 molar ratio and in good yield. The neodymium containing complex was structurally characterized and was used as a single-component catalyst for the controlled ring-opening polymerization of $\varepsilon$-caprolactone giving PCL with a high molecular weight and a narrow molecular weight distribution.

\section{References}

1 Okada M. Prog Polym Sci, 2002, 27: 87

2 Kricheldorf H R, Kreiser-Saunders I, Stricker A. Macromolecules, 2000, 33: 702

3 Dubois P, Jacobs C, Jerome R, Teyssie P. Macromolecules, 1991, 24: 2266

4 Chen H Y, Huang H B, Lin C C. Macromolecules, 2005, 38: 5400

5 Ling J, Zhu W P, Shen Z Q. Macromolecules, 2004, 37: 758
6 Shen Y Q, Shen Z Q, Shen J L, Zhang Y F, Yao K M. Macromolecules, 1996, 29: 3441

7 Xu X, Xu X Y, Chen Y F, Sun J. Organometallics, 2008, 27: 758

8 Yao Y M, Ma M T, Xu X P, Zhang Y, Shen Q, Wong W T. Organometallics, 2005, 24: 4014

9 Arnold P L, Mungur S A, Blake A J, Wilson C. Angew Chem, Int $E d, 2003$, 42: 5981

10 Bambirra S, Bouwkamp M W, Meetsma A, Hessen B. J Am Chem Soc, 2004, 126: 9182

11 Sánchez-Barba L F, Hughes D L, Humphrey S M, Bochmann M. Organometallics, 2006, 25: 1012

12 Yoon T P, Jacobsen E N. Science, 2003, 299: 1691

13 Gupta K C, Sutar A K. Coord Chem Rev, 2008, 252: 1420

14 Drozdzak R, Allaert B, Ledoux N, Dragutan I, Dragutan V, Verpoort F. Coord Chem Rev, 2005, 249: 3055

15 Mason A F, Coates G W. J Am Chem Soc, 2004, 126: 10798

16 Zhu W W, Ni X F, Shen Z Q. Chem J Chin Univ, 2008, 29: 2554

17 Du H Z, Pang X, Yu H Y, Zhuang X L, Chen X S, Cui D M, Wang X H, Jing X B. Macromolecules, 2007, 40:1904

18 Mason A F, Coates G W. J Am Chem Soc, 2004, 126: 16326

19 Gupta K C, Sutar A K. React Funct Polym, 2008, 68: 12

20 Saito J, Onda M, Matsui S, Mitani M, Furuyama R, Tanaka H, Fujita T. Macromol Rapid Commun, 2002, 23: 11181

21 Saito J, Mitani M, Matsui S. Tohi Y, Makio H, Nakano T, Tanaka H, Kashiwa N, Fujita T. Macromol Chem Phys, 2002, 20: 59

22 Grunova E, Kirillov E, Roisnel T, Carpentier J F. Organometallics, 2008, 27: 5691

23 Zhang Z J, Xu X P, Sun S, Yao Y M, Zhang Y, Shen Q. Chem Commun, 2009: 7414

24 Li B Y, Wang Y R, Yao Y M, Zhang Y, Shen Q. J Organomet Chem, 2009, 694: 2409

25 Lu Y, Ni X F, Shen Z Q. Chin J Polym Sci, 2007, 25: 541

26 Peng F, Ling J, Shen Z Q, Zhu W W. J Mol Catal A, 2005, 230: 135 
27 Wu G M, Sun W L, Shen Z Q. J Appl Polym Sci, 2009, 112: 557

28 Wu G M, Sun W L, Shen Z Q. React Funct Polym, 2008, 68: 822

29 Ling J, Zhu W P, Shen Z Q. Macromolecules, 2004, 37:758

30 熊玉兵, 倪旭峰, 樊玲, 沈之荃. 催化学报 (Xiong Y B, Ni
X F, Fan L, Shen Zh Q. Chin J Catal), 2007, 28: 588

31 朱蔚璞, 陈伟, 沈之荃. 催化学报 (Zhu W P, Chen W, Shen Z Q. Chin J Catal), 2007, 28: 547

32 Taylor M D, Carter C P. J Inorg Nucl Chem, 1962, 24: 387

33 Stevels W M, Ankoné M J K, Dijkstra P J. Feijen J. Macromolecules, 1996, 29: 3332 